\title{
WATER EROSION PREDICTION USING THE REVISED UNIVERSAL SOIL LOSS EQUATION (RUSLE) IN A GIS FRAMEWORK, CENTRAL CHILE
}

\author{
Carlos A. Bonilla ${ }^{1 *}$, José L. Reyes ${ }^{1}$, and Antoni Magri²
}

\begin{abstract}
Soil erosion is a growing problem in Central Chile, particularly in coastal dry lands, where it can significantly decrease the productivity of rainfed agriculture and forestry. In this study, the Revised Universal Soil Loss Equation (RUSLE) was integrated into a Geographic Information System (GIS), and used to evaluate the effects of different combinations of vegetative cover on soil erosion rates for Santo Domingo County in Central Chile. Implementing RUSLE in the GIS required a complete description of the county's soils, climate, topography and current land use/ land cover. This information was compiled in rasters of 25 x $25 \mathrm{~m}$ cells. RUSLE parameter values were assigned to each cell and annual soil loss estimates were generated on a cell by cell basis. Soil losses were estimated for the current and for three alternate scenarios of vegetative cover. Under current conditions, $39.7 \%$ of the county is predicted to have low erosion rates $\left(<0.1 \mathrm{t} \mathrm{ha}^{-1} \mathrm{yr}^{-1}\right), 39.8 \%$ has intermediate rates $\left(0.1-1.0 \mathrm{t} \mathrm{ha}^{-1} \mathrm{yr}^{-1}\right)$, and $10.4 \%$ has high erosion rates $\left(>1.1 \mathrm{t} \mathrm{ha}^{-1} \mathrm{yr}^{-1}\right)$. The remainder of the surface $(10.2 \%)$ is not subject to erosion. Under the recommended alternate scenario, $89.3 \%$ of the county is predicted to have low erosion rates, and no areas are affected by high soil loss, reducing soil erosion to a level that will not affect long term productivity. This paper describes how RUSLE was implemented in the GIS, and the methodology and equations used to evaluate the effects of the land use/land cover changes.
\end{abstract}

Key words: RUSLE, water erosion, soil conservation, forestry, changes in land use/land cover, Central Chile.

\section{INTRODUCTION}

Quantitative estimates of soil erosion by water are a key component of land use management plans which are designed to protect and recover soils by prescribing best practices for areas of natural vegetation, agriculture and forestry. Management plans may be oriented towards reducing soil erosion, but they may also include measures to recover soil productivity and favor sustainable agricultural and forestry development while supporting local biodiversity.

Soil erosion by water is an important problem in Chile. IREN-CORFO conducted a study in 1979 which examined $46 \%$ of the continental surface of Chile, and found that high to very high levels of soil erosion affected $36 \%$ of this area (CIREN, 1997). Even though such a

'Pontificia Universidad Católica de Chile, Escuela de Ingeniería, Vicuña Mackenna 4860, Santiago, Chile. "Corresponding author (cbonilla@ing.puc.cl).

${ }^{2}$ Magri Consultores Ltda., Don Carlos 2939, Oficina 613, Santiago, Chile.

Received: 23 January 2008.

Accepted: 07 July 2009. high percentage of the country's land was found to be affected by important levels of soil erosion, quantitative estimates of the magnitudes involved are still scarce. The lack of measurements of soil erosion can be attenuated by performing simulation studies. Many models of soil erosion are available, and can be linked to spatial data management systems, such as geographic information systems (GIS). In practice, both the estimation model and values for each of the variables are incorporated into the GIS. The models can then solved to provide soil loss estimates for each spatial unit of interest. As each variable is represented by a separate layer in the GIS, parameter values can be adjusted in order to study the effects of different management scenarios (Almorox et al., 1994).

One the of estimation models that is most widely used is the Revised Universal Soil Loss Equation (RUSLE, Renard et al., 1997). RUSLE is an empirical, parametric model which has been tested and validated under diverse soil, climate and management conditions. RUSLE is an equation based on the main factors that affect soil erosion (Renard et al., 1997): 
where $\mathrm{A}$ is soil loss $\left(\mathrm{t} \mathrm{ha}^{-1} \mathrm{yr}^{-1}\right), \mathrm{R}$ is the rainfall erosivity factor (MJ mm ha-1 $\left.\mathrm{h}^{-1} \mathrm{yr}^{-1}\right), \mathrm{K}$ is the soil erodibility factor $\left(\mathrm{t} \mathrm{h} \mathrm{MJ}-1 \mathrm{~mm}^{-1}\right.$ ), $\mathrm{L}$ is the slope length factor, $\mathrm{S}$ is the steepness factor, $\mathrm{C}$ is the cover-management factor, and $\mathrm{P}$ is a factor that accounts for the effects of soil conservation practices. Parameters L, S, C and P are adimensional.

RUSLE and its predecessor USLE have been widely used around the globe (Mitasova et al., 1996; Tiwari et al., 2000; Amore et al., 2004) and in Chile (Brito and Peña, 1980; Peña, 1983; 1985; Oyarzún, 1993; Honorato et al., 2001). The majority of these studies have demonstrated the accuracy of RUSLE's predictions, which appears to be greatest for terrains with softly undulating slopes. Recently, the use of GIS has permitted RUSLE estimates to be generated by overlaying layers of the equations' parameters (Lu et al., 2004; Zhou et al., 2008; Kouli et al., 2009). Organizing terrain information in GIS layers makes the implementation of RUSLE particularly interesting when evaluating different vegetative covers in order to reduce soil erosion. Brath et al. (2002) analyzed the effects of soil use on erosion using a regional application of RUSLE based on information on terrain morphology, climate, soil and soil use. Their analysis demonstrated that changes in land use affected annual soil loss rates.

The soils of Santo Domingo County (located in the Valparaiso Region of Chile) have traditionally been used for agriculture, primarily for wheat and livestock, as well as some legumes and vegetables (Gastó et al., 2002). Over the last few years, large areas of natural forest have been converted to intensive wheat production, even in areas where slopes are steep enough that wheat cultivation is not recommended. Many of the remaining areas of natural forest have been thinned for cattle and some species have been cut for firewood. Changes in, or the complete elimination of vegetative cover in the county have caused increased rates of soil erosion.

The link between vegetation and hydrologic processes is especially strong in environments that have limited availability of water. Vegetation in these types of environments depends strongly on surface runoff, and plays an important role in controlling soil erosion (Bathurst et al., 2007; Saco et al., 2007). Even though there is general agreement that soil erosion diminishes its productivity, there is no consensus on a critical soil-loss tolerance. Depending on local conditions, soil-loss tolerance values vary between 2 and $12 \mathrm{t} \mathrm{ha}^{-1} \mathrm{yr}^{-1}$ (Renard et al., 1997). Due to this, the objectives of this study were to estimate the levels of soil erosion in Santo Domingo County, and to propose a vegetative cover scenario that would reduce soil loss to levels that would not endanger the soil's long term productivity. The more conservative value of $2 \mathrm{t} \mathrm{ha}^{-1} \mathrm{yr}^{-1}$ was used in this study, and is considered appropriate given the soil and climatic conditions of the region.

\section{MATERIALS AND METHODS}

Santo Domingo County is located between $33^{\circ} 37^{\prime} \mathrm{S}$ and $33^{\circ} 57^{\prime} \mathrm{S}$, and $71^{\circ} 50^{\prime} \mathrm{W}$ and $71^{\circ} 33^{\prime} \mathrm{W}$. It has a total surface area of 53543 ha (Figure 1), and has traditionally been used for agriculture. The county's climate is semiarid with a marked marine influence. Annual rainfall is $445 \mathrm{~mm}$, concentrated in the winter months. The marine influence moderates air temperature, which rarely exceeds $25^{\circ} \mathrm{C}$ or drops below $5{ }^{\circ} \mathrm{C}$ (Gastó et al., 2002). Topographically, the county consists of gentle hills (Gastó et al., 2002). Approximately $50 \%$ of the surface has slopes less than $5 \%$ (Table 1). The majority of the soils belong to the Santo Domingo series or to the La Manga (Mollic Haploxeralfs) and Matanzas (Oxic Haplustolls) (CIREN, 1997), which are clay loam to sandy loam in texture, moderate in depth and permeability, and between 1 and $4 \%$ organic matter. Most of the soils have a land use rating of IV or greater (limited suitability for row crops), and support brush or native forest. Small areas have soils with land use ratings of II, III or IV (apt for row crops), and are used for agriculture (Gastó et al., 2002). Currently, most of the county is divided into small lots and farms. Grasslands are used for livestock production. Natural vegetation consists of thorny brush and native forest, but plantations of pine

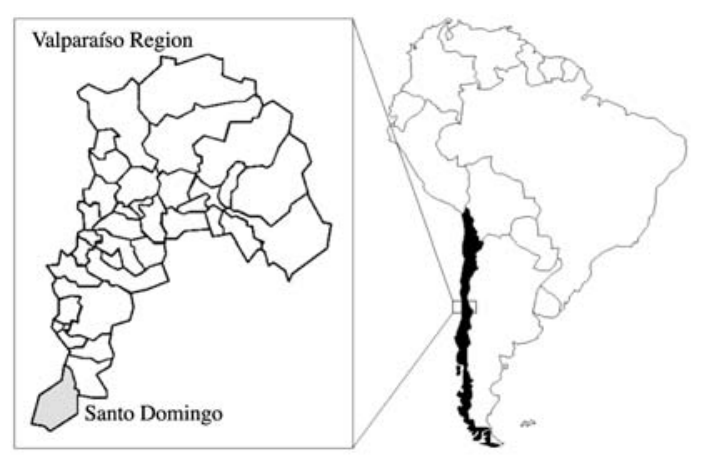

Figure 1. Location of Santo Domingo County in Central Chile.

Table 1. Land distribution as a function of slope in Santo Domingo County.

\begin{tabular}{lcc}
\hline Slope & \multicolumn{2}{c}{ Surface } \\
\hline$\%$ & ha & $\%$ \\
0 & 20506 & 38.3 \\
$0-2$ & 3266 & 6.1 \\
$2-5$ & 3908 & 7.3 \\
$5-12$ & 11618 & 21.7 \\
$12-25$ & 5407 & 10.1 \\
$25-40$ & 6050 & 11.3 \\
$>40$ & 2784 & 5.2 \\
\hline
\end{tabular}


(Pinus radiata D. Don.) and eucalyptus (Eucalyptus globulus Labill.) also exist. Recently, intensive wheat production has replaced large areas of native forest (composed of evergreen, sclerophyllous and broadleaf species). Other areas of native brush and forest have been affected by the expansion of livestock enterprises and by the extraction of some species for firewood (Gastó et al., 2002). These changes have led to increasing areas of the county affected by water erosion.

\section{Parameter estimation for RUSLE}

Daily rainfall recorded by the San Antonio (33 $34^{\prime}$ S, $\left.71^{\circ} 27^{\prime} \mathrm{W}\right)$ and Rapel ( $\left.33^{\circ} 57^{\prime} \mathrm{S}, 71^{\circ} 44^{\prime} \mathrm{W}\right)$ weather stations between 1978 and 1997 (19 years) was used to estimate values for $\mathrm{R}$. Both stations are run by the Dirección General de Aguas (DGA), which is a part of the Ministerio de Obras Públicas. Due to a lack of high temporal detail in the rainfall records, it was not possible to compute $\mathrm{R}$ as defined by Renard et al. (1997). Instead, values for R were estimated using an empirical approximation proposed by ICONA (1988), which has shown satisfactory results for areas with $<500 \mathrm{~mm}$ annual rainfall. The following is the approximation proposed by ICONA (1988):

$$
\mathrm{R}=10 \mathrm{f} \mathrm{PI}_{1.2} \mathrm{I}_{24.2}
$$

where $\mathrm{f}$ is a zonal coefficient (equal to 0.00035 ), $\mathrm{P}$ is the average annual rainfall $(\mathrm{mm})$, and $\mathrm{I}_{1.2}$ and $\mathrm{I}_{24.2}$ are the maximum rainfall in 1 and $24 \mathrm{~h}$ for a 2 -yr return period, respectively.

Maximum rainfall in 1 and $24 \mathrm{~h}$ for a 2 -yr return period were obtained by fitting a log-normal model to the data. Model fit was verified using a $\chi^{2}$ test. Maximum rainfall in $1 \mathrm{~h}$ was obtained by fitting a curve to the 24,48 and 72 $\mathrm{h}$ rainfall values. As the stations are located at different extremes of Santo Domingo County (San Antonio to the North and Rapel to the South), a difference in mean annual precipitation was detected. Within the county, mean annual precipitation values were determined as a function of distance to each station. This resulted in 10 horizontal bands (isopleths) which show a progressive increase in precipitation from North to South.

The $\mathrm{K}$ factor (soil erodibility) was calculated by means of an equation proposed by Wischmeier and Smith (1978) for soils that have silt contents of $70 \%$ or less:

$$
\begin{gathered}
\mathrm{K}=\left[2.1 \cdot 10^{-4} \mathrm{M}^{1.14}(12-\mathrm{OM})+3.25(\mathrm{~s}-2)+\right. \\
2.5(\mathrm{p}-3)] / 759
\end{gathered}
$$

where $\mathrm{OM}$ is the soil organic matter content $(\%)$, and $\mathrm{M}$ is a particle size parameter which is estimated by multiplying the silt percentage (particles of 0.002 to 0.1 $\mathrm{mm}$ in size) by (100 - \% clay). The $\mathrm{s}$ and $\mathrm{p}$ parameters describe soil structure and permeability, as defined in the U.S. Soil Survey Manual (USDA, 1951).

Organic matter, sand and clay contents, as well as permeability and structure values for the top layer of soil were obtained from soil surveys (CIREN, 1997) for each series and association of soils. The $\mathrm{L}$ and $\mathrm{S}$ factors were calculated using the equations defined by Wischmeier and Smith (1978) based on the slope's length and gradient, which were obtained from a digital elevation model (DEM) with a cell size of $25 \times 25 \mathrm{~m}$. The DEM was built based on 1:50 000 topographic maps (IGM, 1990). The cover-management $\mathrm{C}$ factor was determined for each type of vegetative cover and soil management scheme, based on the values proposed by Wischmeier and Smith (1978) and on descriptions of the vegetative communities that occur in the county (CONAF-JICA, 1998). As no information was available regarding soil conservation practices, $\mathrm{P}$ was assumed to be 1 throughout the county. This provides worst-case soil erosion estimates, as no soil conservation practices are assumed to be in place.

\section{GIS implementation}

RUSLE was implemented in GIS using ArcView 3.1 (ESRI, Redlands, California, USA) software. Values for $\mathrm{R}, \mathrm{K}, \mathrm{L}, \mathrm{S}, \mathrm{C}$ and $\mathrm{P}$ were input as independent layers (Figure 2). Each layer was a raster of $25 \times 25 \mathrm{~m}$ cells (625 $\mathrm{m}^{2}$ per cell). RUSLE was expressed as a Map Algebra expression, and solved for each cell. This implementation allows parameter values to easily be altered in order to evaluate the effects of alternate vegetative covers on soil erosion.

\section{Vegetative cover scenarios}

Soil erosion was estimated for the county under current vegetative conditions and for three alternate scenarios where vegetative cover was altered in order to achieve acceptable rates of soil erosion. Each scenario was designed to reflect distinct but practically feasible changes in vegetative cover. Results were analyzed by comparing soil erosion rates with the associated vegetative cover (species, age and density for forest, and species and agricultural practices for crops). In scenario 1, we assumed that all mixed brush and areas of mixed succulent plants are reforested by planting native forest species. Soil conservation practices are implemented in agricultural areas, and communities of native forest and rangelands are planted with native species that have demonstrated capacity for reducing soil erosion. In scenario 2, mixed brush and native succulent plants are completely replaced by eucalyptus forest. This affords protection against erosion in less time than if native species were used to reforest these areas (as in scenario 1). Soil conservation practices are implemented in agricultural areas, and native forest 


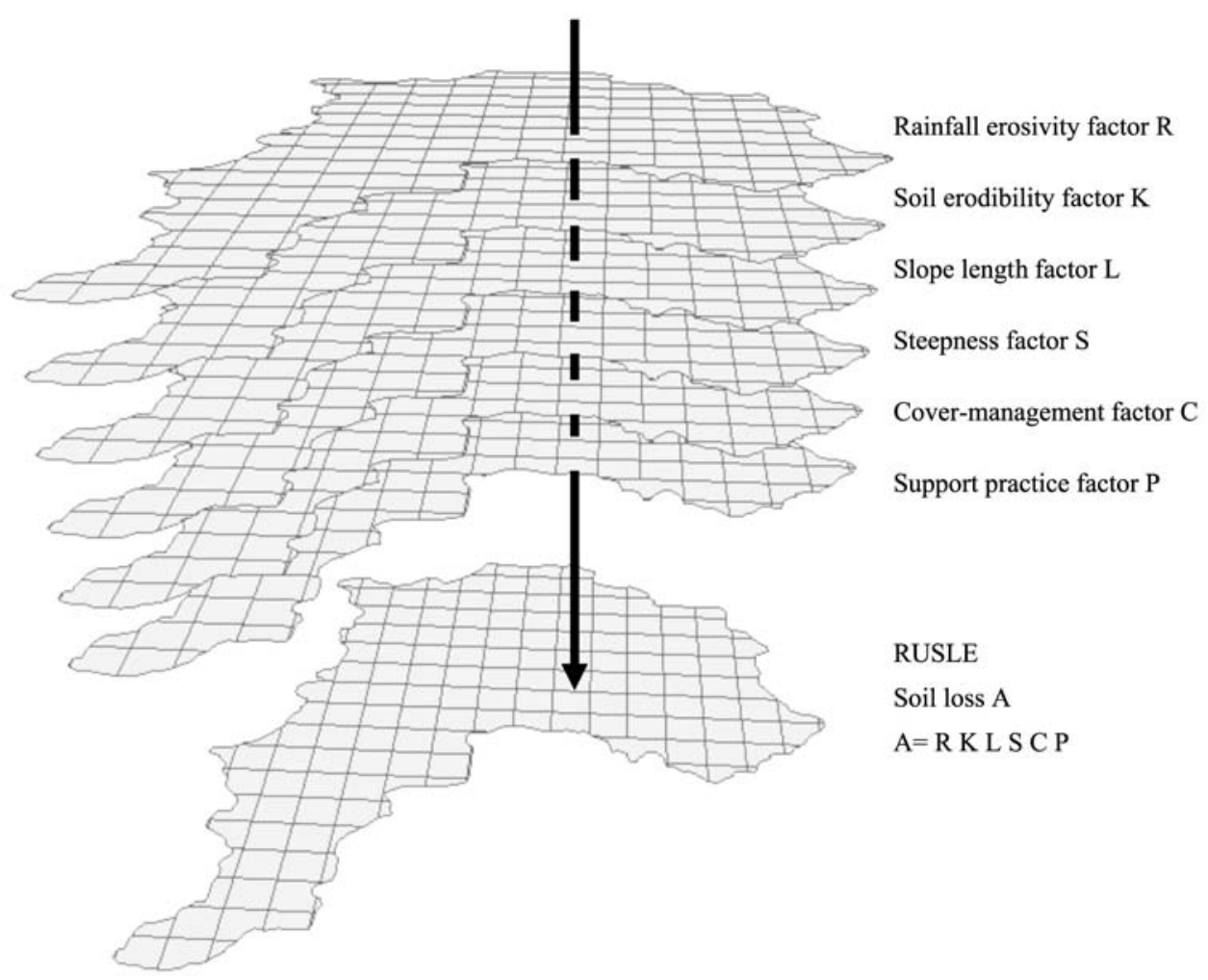

Figure 2. Revised Universal Soil Loss Equation (RUSLE) implementation in the Geographic Information System (GIS). The superposition of the layers in the GIS allows RUSLE parameters to be assigned to each cell, and soil erosion by water is estimated on a cell by cell basis.

and rangelands are planted with native species that have demonstrated capacity for reducing soil erosion. Finally, in scenario 3, areas of mixed brush and native succulent plants are managed using a mixture of soil erosion control measures, including reforestation with native species and replacement of some areas with commercial forests. Soil conservation practices are implemented in agricultural areas, and native forest and rangelands are planted with native species that have demonstrated capacity for reducing soil erosion. Changes in vegetative cover were implemented by creating a layer of $\mathrm{C}$ factor values for each scenario (based on recommended values published by Wischmeier and Smith, 1978).

\section{RESULTS AND DISCUSSION}

\section{RUSLE parameter values}

Values for R in Santo Domingo County are similar to or lower than other estimates for Central Chile. $\mathrm{R}$ values for the San Antonio and Rapel weather stations were 289 and $415 \mathrm{MJ} \mathrm{mm} \mathrm{ha}^{-1} \mathrm{yr}^{-1}$, respectively. In contrast, Honorato et al. (2001) reported values of $800 \mathrm{MJ} \mathrm{mm} \mathrm{ha}^{-1} \mathrm{yr}^{-1}$ for Central Chile and $2000 \mathrm{MJ} \mathrm{mm} \mathrm{ha}^{-1} \mathrm{yr}^{-1}$ for Southern Chile. The soil erodibility values $\mathrm{K}$ for the county are presented in Table 2. Soil erodibility varies between 0.019 and $0.078 \mathrm{t}$ ha h ha ${ }^{-1} \mathrm{MJ}^{-1} \mathrm{~mm}^{-1}$. Previous studies have found $\mathrm{K}$ values that vary between 0.022 and $0.040 \mathrm{t}$ ha $\mathrm{h}$ $\mathrm{ha}^{-1} \mathrm{MJ}^{-1} \mathrm{~mm}^{-1}$ (Honorato et al., 2001). The $\mathrm{L}$ and $\mathrm{S}$ factors for the county have relatively low values, mainly because the county's topography consists of mildly rolling hills and flat areas. Much of the county has LS values of 0.6 or less. These LS values are similar to those reported by Honorato et al. (2001) for the central and southern regions of Chile.

Estimated $\mathrm{C}$ values are high for most communities in the county, except for dense native and commercial forests (Table 3). The $\mathrm{C}$ values for sparse and semidense native forests are high because they are subject to frequent extractions for firewood. Native forests, in their undisturbed state, should have $\mathrm{C}$ values close to 0.004 . Native succulent and mixed brush communities have high $\mathrm{C}$ values due to low plant density, caused by livestock intrusion and removal for firewood. In their undisturbed state, brush of this nature should have $\mathrm{C}$ values close to 0.006 . $\mathrm{C}$ values for forest plantations depend on the age of the trees and on forest management practices. In this study, trees were assumed to be mature. Average C values may be a little underestimated (as the average $\mathrm{C}$ 
Table 2. Basic properties of the top soil layer, and soil erodibility factor K for soil series in Santo Domingo County.

\begin{tabular}{|c|c|c|c|c|c|c|c|c|}
\hline Soil & Soil taxonomy & Clay & Silt & Sand & $\begin{array}{c}\text { Organic } \\
\text { matter }\end{array}$ & $\mathbf{p}$ & $\mathbf{s}$ & $\mathbf{K}$ \\
\hline & & \multicolumn{4}{|c|}{$-\mathrm{g} \mathrm{kg}^{-1}$} & & & $\mathrm{MJ}^{-1} \mathrm{~mm}^{-1}$ \\
\hline Lo Vásquez & Ultic Haploxeralfs & 148 & 294 & 558 & 19 & 2 & 4 & 0.039 \\
\hline Santa Rita de Casa Blanca & Typic Xerochrepts & 88 & 210 & 702 & 41 & 2 & 4 & 0.026 \\
\hline Santo Domingo & Typic Xerochrepts & 61 & 86 & 853 & 5 & 1 & 4 & 0.019 \\
\hline Tronador & Vertic Haploxerolls & 615 & 331 & 54 & 31 & 6 & 4 & 0.018 \\
\hline Cuzco & Dystric Entic Durochrepts & 136 & 170 & 692 & 12 & 2 & 4 & 0.025 \\
\hline La Manga & Mollic Haploxeralfs & 321 & 210 & 469 & 15 & 4 & 4 & 0.019 \\
\hline Matanza & Oxic Haplustolls & 152 & 373 & 474 & 38 & 3 & 4 & 0.042 \\
\hline Recent terraces & & 100 & 250 & 650 & 5 & 2 & 3 & 0.075 \\
\hline Miscelaneous & & 70 & 120 & 810 & 2 & 1 & 3 & 0.078 \\
\hline
\end{tabular}

$\mathrm{p}$ and s are the permeability and soil structure indices used to compute K according to Wischmeier and Smith (1978).

Table 3. Cover-management factors $\mathrm{C}$ determined for Santo Domingo County based on combinations of vegetative cover and land use.

\begin{tabular}{|c|c|c|c|c|}
\hline \multirow[b]{2}{*}{ Land use/land cover } & \multirow{2}{*}{$\begin{array}{c}\text { Current } \\
\text { condition }\end{array}$} & \multicolumn{3}{|c|}{ Scenario } \\
\hline & & 1 & 2 & 3 \\
\hline Native forest-sparce & 0.05 & 0.004 & 0.004 & 0.004 \\
\hline Native forest-dense & 0.009 & 0.004 & 0.004 & 0.004 \\
\hline Native forest-intermediate (semi-dense) & 0.03 & 0.004 & 0.004 & 0.004 \\
\hline Reservoir & 0 & 0 & 0 & 0 \\
\hline Stream & 0 & 0 & 0 & 0 \\
\hline Wetland & 0 & 0 & 0 & 0 \\
\hline Lagoon & 0 & 0 & 0 & 0 \\
\hline Mixed brush & 0.13 & & & \\
\hline Reforested & & 0.006 & & 0.006 \\
\hline Replaced by Eucalyptus globulus & & & 0.001 & \\
\hline Replaced by E. globulus or Pinus radiata & & & & 0.001 \\
\hline Rangeland & 0.038 & 0.006 & 0.006 & 0.006 \\
\hline Native succulent brush & 0.13 & & & \\
\hline Reforested & & 0.006 & & 0.006 \\
\hline Replaced by E. globulus & & & 0.001 & \\
\hline Replaced by E. globulus or P. radiata & & & & 0.001 \\
\hline Commercial forest & 0.01 & 0.01 & 0.01 & 0.01 \\
\hline River & 0 & 0 & 0 & 0 \\
\hline Marsh & 0 & 0 & 0 & 0 \\
\hline No vegetative cover (bare) & 0 & 0 & 0 & 0 \\
\hline Agricultural soil & 0.1 & 0.1 & 0.1 & 0.1 \\
\hline with soil conservation practices & & 0.01 & 0.01 & 0.01 \\
\hline Beaches & 0 & 0 & 0 & 0 \\
\hline
\end{tabular}

value for a 20-yr life span was not used), but there was insufficient information available to adjust the values with any confidence. In agricultural areas, $\mathrm{C}$ values were determined for winter wheat (Triticum sativum L.), and could be reduced if soil conservation practices are implemented. $\mathrm{C}$ values of 0 were assigned to areas where soil erosion levels are insignificant or zero. 
Soil loss under current conditions and alternate scenarios

Estimated soil loss due to water erosion under current conditions is shown in Figure 3. Percentages of area for each class of soil loss are shown in Table 4. Results show that $39.73 \%$ of the county is predicted to have low erosion rates $\left(<0.1 \mathrm{t} \mathrm{ha}^{-1} \mathrm{yr}^{-1}\right), 39.79 \%$ has intermediate erosion rates $\left(0.1\right.$ to $\left.1.0 \mathrm{t} \mathrm{ha}^{-1} \mathrm{yr}^{-1}\right)$, and $10.40 \%$ has high erosion rates (1.1 to 6.0 or 6.1 to $8.0 \mathrm{t} \mathrm{ha}^{-1} \mathrm{yr}^{-1}$ ). The remaining $10.2 \%$ is non-erodible (marshes, beaches and water bodies). These results match measurements from soil erosion plots located in Alto Loica in San Pedro County, which is directly South of Santo Domingo County and has similar precipitation, soils, topography and land use practices (CONAF-JICA, 1998).

Almost $30 \%$ of the county's land is used for agriculture, which consists mostly of wheat. Some of these soils have slopes close to $25 \%$, and, in this study, it was assumed that no erosion control practices were implemented to mitigate soil loss. In contrast, $11 \%$ of the county is covered by eucalyptus and pine forest, which offer good protection against the erosive effects of rainfall. Estimated erosion levels are low for forest plantations, even on slopes above 20\%. Brushlands (succulent and mixed) show high levels of erosion, which is explained by the low plant density rather than characteristics of the species themselves. Huingan (Schinus polygamus (Cav.) Cabrera) and thorn trees (Acacia caven [Molina] Molina) offer good protection against erosion. Erosion rates in brushlands increase with steeper slopes, which are frequently above $10 \%$. Native forest and rangelands show intermediate erosion rates. This again is due to low plant density, mainly because of human intervention and the use of these lands for livestock.

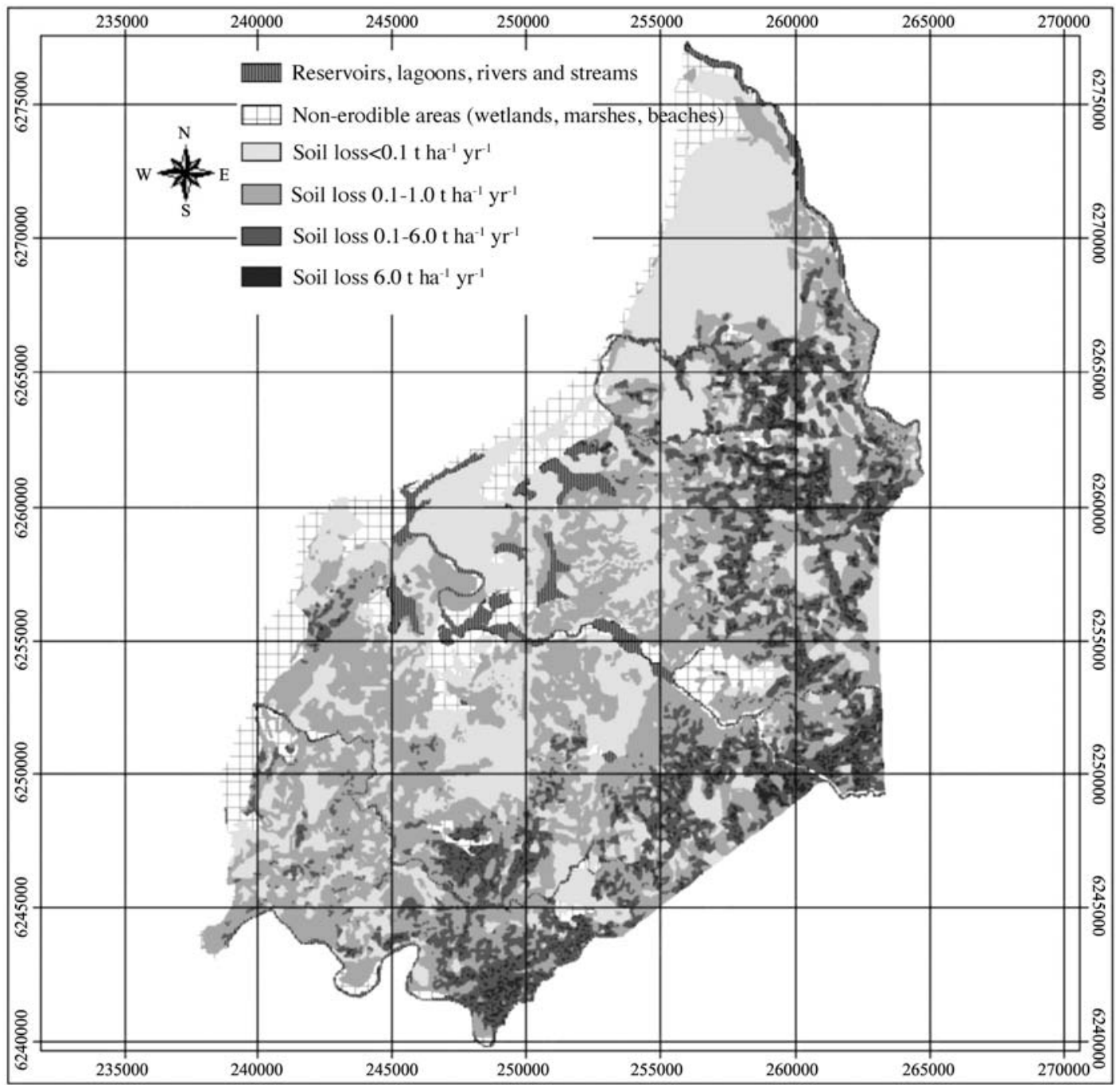

Figure 3. Estimated soil erosion by water under the current condition for Santo Domingo County. 
The cover-management factor values for scenario 1 are shown in Table 3, and the area corresponding to each soil erosion rate is shown in Table 4. Values in Table 4 reflect changes in vegetation: brushlands (succulent and mixed), rangelands and native forests have been reforested and erosion control practices (e.g. contour cropping, incorporating organic matter, better grazing control and fertilization) have been implemented in agricultural soils. These changes result in a considerable decrease in the surface area affected by high and intermediate erosion rates. This is due to more effective soil protection offered by increasing plant density with species that have demonstrated erosion control qualities. Soil conservation practices are also effective in protecting agricultural soils.

Results and $\mathrm{C}$ factor values for scenario 2 are shown in Tables 3 and 4. This scenario shows a significant reduction in soil loss as compared to the current situation. No areas are predicted to have high or intermediate erosion rates, and almost all the county lands have low erosion rates. This is mainly due to the replacement of brushland by eucalyptus forest, in addition to the effects of soil conservation practices in rangelands, native forest and agricultural soils.

Results for scenario 3 are shown in Table 4. This scenario also shows a considerable decrease in soil erosion with respect to the current situation. No areas are predicted to have high erosion rates, and the amount of land affected by intermediate erosion levels is reduced to $0.5 \%$. Vegetative cover resulting from mixed management of brushlands, reforestation of native forests and rangelands, and soil conservation practices in agricultural areas offer adequate protection against the erosive effects of rainfall in this region.

\section{Proposed vegetative cover for soil erosion control}

Scenarios 1,2 and 3 were designed to reduce average annual loss to less than $2 \mathrm{t} \mathrm{ha}^{-1} \mathrm{yr}^{-1}$. As the target is an average annual loss, the selection of a recommended vegetative cover must consider the time required for it to reach full soil protection, as well as the impacts incurred when establishing it. Pine and eucalyptus forests are estimated to require $8 \mathrm{yr}$ before achieving full soil protection (Bathurst et al., 1998; CONAF-JICA, 1998). Brush and native forest take up to $30 \mathrm{yr}$ (Tsuruta, 1999). Given that erosion control measures for rangeland, agricultural soil and native forest are the same for all three scenarios; our choice of vegetative cover is driven by the management of brushlands. In scenario 1 , brushlands which exhibit high erosion rates (close to $6 \mathrm{tha}^{-1} \mathrm{yr}^{-1}$ ) are subjected to a strategy (replacement with native forest) that requires 30 yr to achieve adequate protection. In scenario 2, however, the strategy (pine and eucalyptus forest) requires only 8 $\mathrm{yr}$, but causes important disruptions to the harmony of the ecosystem. The mixed strategy evaluated in scenario 3 causes less disruption of the ecosystem, and the surface of brushland that must be substituted for commercial forest is small. The management scheme proposed in scenario 3 creates new ecological niches, protects the soil in less time and recovers less eroded soils by planting native species, and thus, it is recommended as the most adequate of the three for Santo Domingo County. Overall soil erosion would be reduced to acceptable levels while causing less ecological alteration than scenarios 1 and 2 . Vegetative cover for scenario 3 is shown in Figure 4, and corresponding soil loss values are shown in Figure 5.

\section{CONCLUSIONS}

Implementation of RUSLE in GIS allowed rapid evaluation of diverse scenarios designed to reduce existing soil loss rates in Santo Domingo County. Currently, $39.7 \%$ of the county is predicted to have low erosion $\left(<0.1 \mathrm{t} \mathrm{ha}^{-1} \mathrm{yr}^{-1}\right), 39.8 \%$ has intermediate erosion ( 0.1 to $1.0 \mathrm{t} \mathrm{ha}^{-1} \mathrm{yr}^{-1}$ ), and $10.4 \%$ has high erosion rates (> $1.1 \mathrm{t} \mathrm{ha}^{-1} \mathrm{yr}^{-1}$ ). The remaining $10.2 \%$ corresponds to non-erodible areas. Under current conditions, low erosion rates are due to the low to intermediate erosive capacity of the rainfall events, and occur in areas of

Table 4. Land distribution according to estimated soil erosion under the current and proposed vegetative cover scenarios.

\begin{tabular}{|c|c|c|c|c|c|c|c|c|}
\hline \multirow{3}{*}{$\begin{array}{l}\begin{array}{l}\text { Range of } \\
\text { soil erosion }\end{array} \\
t h a^{-1} \mathrm{yr}^{-1}\end{array}$} & \multirow{2}{*}{\multicolumn{2}{|c|}{ Current condition }} & \multicolumn{6}{|c|}{ Scenario } \\
\hline & & & \multicolumn{2}{|c|}{1} & \multicolumn{2}{|c|}{2} & \multicolumn{2}{|c|}{3} \\
\hline & ha & $\%$ & ha & $\%$ & ha & $\%$ & ha & $\%$ \\
\hline Non-erodible & 5466 & 10.2 & 5466 & 10.2 & 5466 & 10.2 & 5466 & 10.2 \\
\hline$<0.1$ & 21272 & 39.7 & 47599 & 88.9 & 48076 & 89.8 & 47787 & 89.3 \\
\hline $0.1-1.0$ & 21304 & 39.8 & 428 & 0.8 & 0 & 0.0 & 289 & 0.5 \\
\hline $1.1-6.0$ & 5215 & 9.7 & 43 & 0.1 & 0 & 0.0 & 0 & 0.0 \\
\hline $6.1-8.0$ & 289 & 0.5 & 0 & 0.0 & 0 & 0.0 & 0 & 0.0 \\
\hline Total & 53543 & 100 & 53543 & 0.0 & 53543 & 100 & 53543 & 100 \\
\hline
\end{tabular}




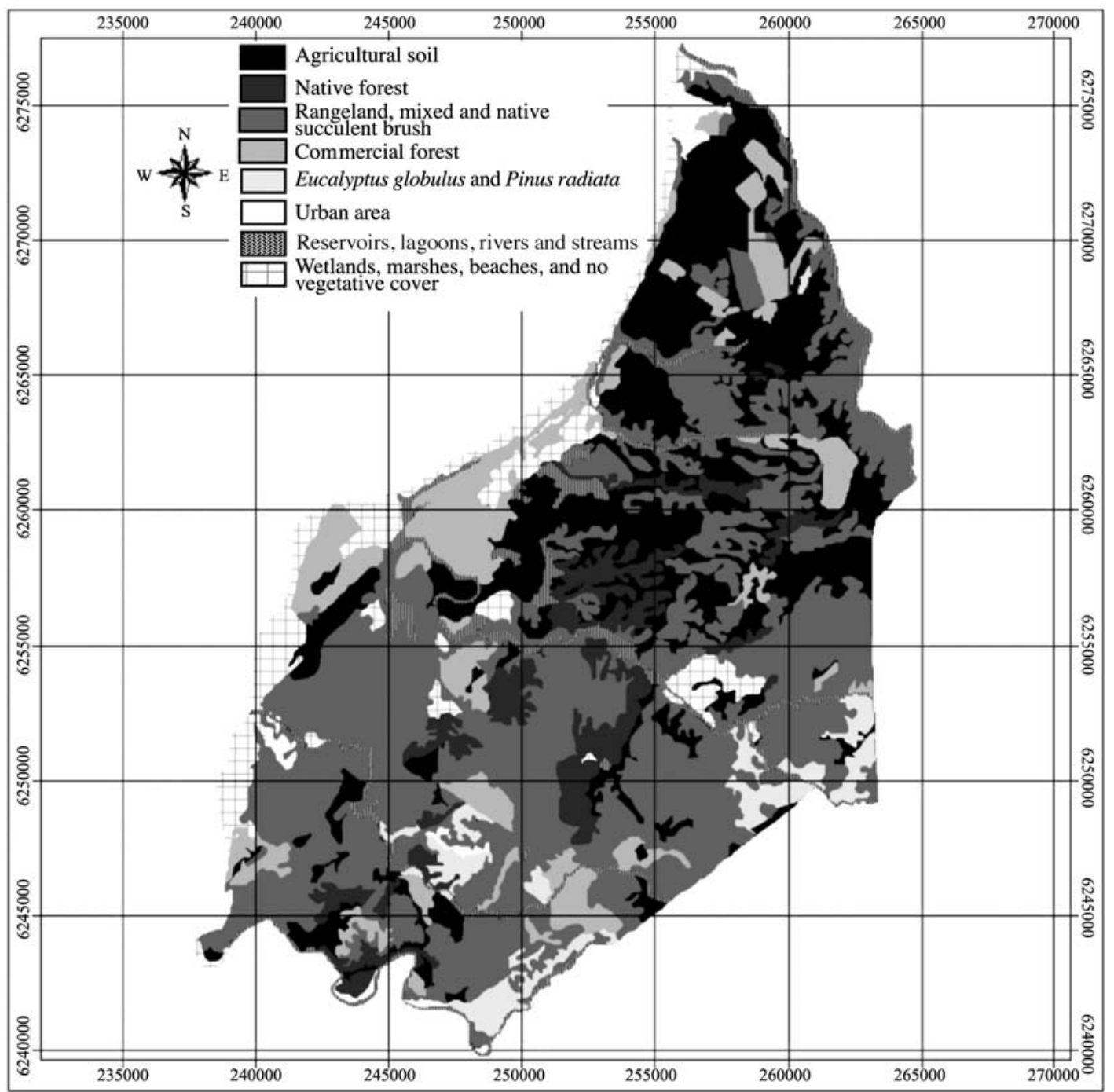

Figure 4. Recommended vegetative cover to reduce soil loss in Santo Domingo County (scenario 3).

gentle slopes and vegetation such as forest plantations, which provide adequate soil protection. Intermediate erosion rates occur in areas of steeper slopes, undulating terrain and vegetative cover such as dense native forest and rangelands, which provides some protection. High erosion rates occur on steep slopes ( $>25 \%$ ), undulating terrain, degraded vegetative cover (sparse native forest, succulent and mixed brush), and on land dedicated to wheat. By defining layers of different vegetative cover in the GIS, we determined that soil loss rates for Santo Domingo County could be reduced to a level which would not affect soil productivity in the long run. Recommended vegetative cover is composed of brush (succulent and mixed), rangeland and native forest, and is used in addition to soil conservation practices in agricultural areas and by planting forest species of rapid growth and demonstrated erosion control qualities.

\section{ACKNOWLEDGEMENTS}

This research was partially supported with funds from the Fondo Nacional de Desarrollo Científico y Tecnológico (FONDECYT-CONICYT, Chile), grant number 11075057, and Vicerrectoría Adjunta de Investigación y Doctorado (VRAID- Pontificia Universidad Católica de Chile), grant number 13/2007. Rainfall data was provided by the Dirección General de Aguas (DGA), Government of Chile. 


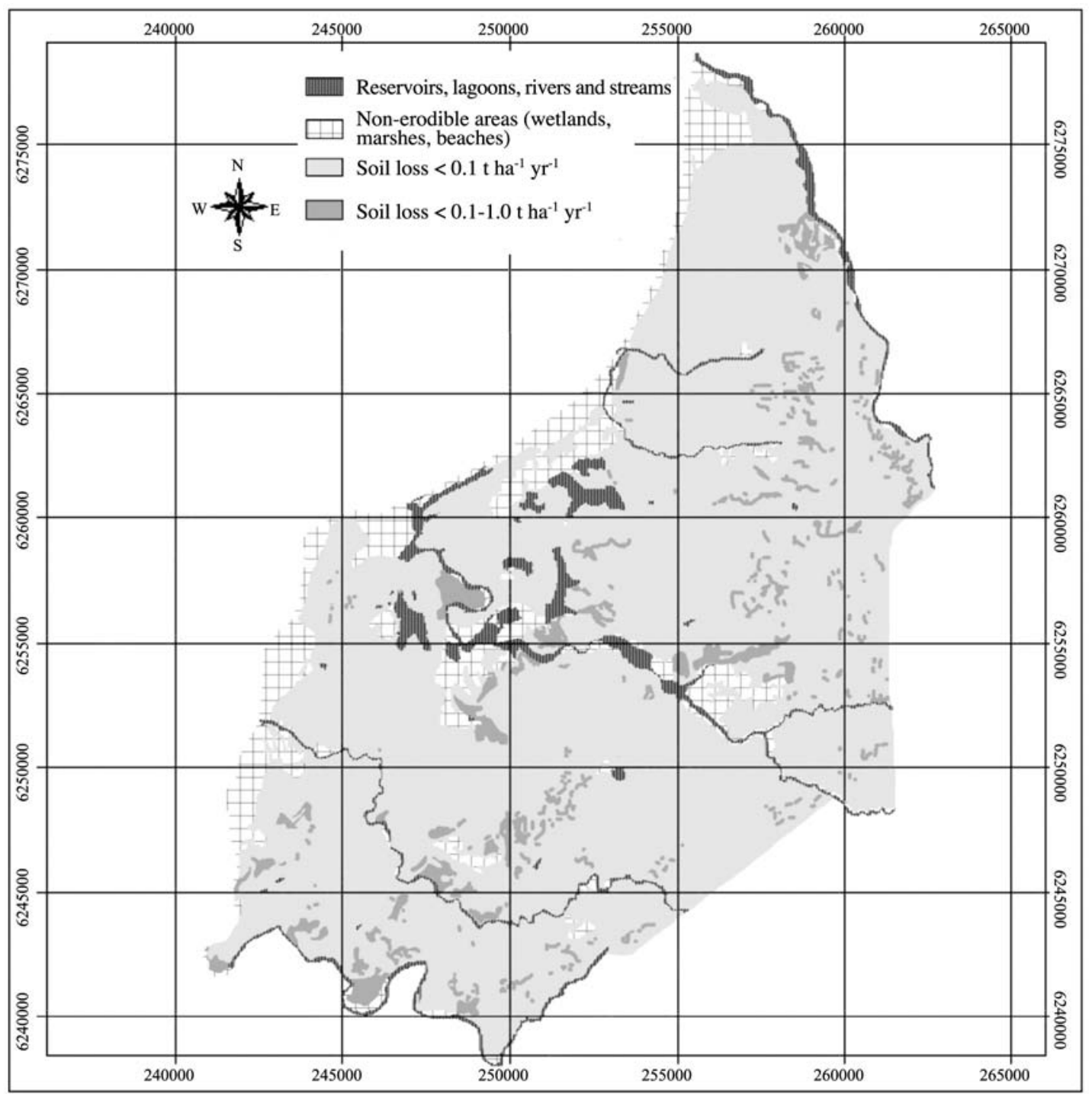

Figure 5. Estimated soil erosion by water under the recommended scenario for Santo Domingo County (scenario 3).

\section{RESUMEN}

Estimación de la erosión hídrica empleando la Ecuación Universal de Pérdida de Suelo Revisada (RUSLE) y SIG en Chile Central. La erosión hídrica es un problema creciente en la Zona Central de Chile, especialmente en el Secano Costero, donde reduce la productividad de los suelos agrícolas y forestales. En este trabajo se empleó la Ecuación Universal de Pérdida de Suelo Revisada (RUSLE) integrada a un Sistema de Información Geográfica (GIS) para evaluar el efecto de distintas combinaciones de cubierta vegetal en las tasas de erosión en la comuna de Santo Domingo, Chile. La implementación de RUSLE en el GIS requirió la caracterización de suelos, clima, relieve y uso actual del territorio. La información se compiló en grillas con celdas de $25 \times 25 \mathrm{~m}$ y el valor de los parámetros de RUSLE se asignó en el GIS a cada celda. Se calculó la erosión en la condición actual y en tres escenarios posibles de cubierta vegetal. Bajo la condición actual, se estima que $39,7 \%$ de la superficie presenta niveles de erosión bajos $\left(<0,1 \mathrm{t} \mathrm{ha}^{-1}\right.$ año $\left.{ }^{-1}\right), 39,8 \%$ niveles medios $\left(0,1-1,0 \mathrm{t} \mathrm{ha}^{-1}\right.$ año ${ }^{-1}$ y $10,4 \%$ niveles altos $\left(>1,0 \mathrm{t} \mathrm{ha}^{-1}\right.$ año $\left.^{-1}\right)$. El resto de la superficie $(10,2 \%)$ son terrenos no erosionables. Se seleccionó uno de los tres escenarios para reducir la erosión y no amenazar el potencial productivo de los suelos. Bajo el escenario seleccionado, se estima que $89,3 \%$ de la superficie presenta nivel de erosión bajo, y no se registran áreas con niveles altos. Este artículo describe la implementación de RUSLE en el GIS, y la metodología 
utilizada para evaluar los efectos de la cubierta vegetal en la erosión hídrica.

Palabras clave: RUSLE, erosión hídrica, conservación de suelo, reforestación, cambios en el uso/cobertura del suelo, Chile Central.

\section{LITERATURE CITED}

Almorox, J., R. de Antonio, A. Saa, M.C. Díaz, and J.M. Gasco. 1994. Métodos de estimación de la erosión hídrica. 152 p. Ed. Agrícola Española, S.A., Madrid, España.

Amore, E., C. Modica, M.A. Nearing, and V.C. Santoro. 2004. Scale effect in USLE and WEPP application for soil erosion computation from three Sicilian basins, J. Hydrol. 293:100-114.

Bathurst, J., S. Birkinsshaw, J. Evans, y S. Francke. 1998. Modelo de bases físicas para la predicción de los impactos hidrológicos y la erosión de los suelos provocados por opciones de la gestión forestal. Documento Técnico $\mathrm{N}^{\circ} 120.8$ p. Chile Forestal, Santiago, Chile.

Bathurst, J.C., G. Moretti, A. El-Hames, S. Beguería, and J.M. García-Ruiz. 2007. Modelling the impact of forest loss on shallow landslide sediment yield, Ijuez river catchment, Spanish Pyrenees. Hydrol. Earth Syst. Sci. 11:569-583.

Brath, A., A. Castellarin, and A. Montanari. 2002. Assessing the effects of land-use changes on annual average gross erosion. Hydrol. Earth Syst. Sci. 6:255265.

Brito, J., y L. Peña. 1980. Determinación del factor "R" de la ecuación universal de predicción de erosión hídrica en la provincia de Ñuble. Agric. Téc. (Chile) 40:152-156.

CIREN. 1997. Estudio agrológico de la V Región. Publicación $\mathrm{N}^{\circ} 116.170$ p. Tomo I. Centro de Información de Recursos Naturales (CIREN), Santiago, Chile.

CONAF-JICA. 1998. Control de erosión y forestación en cuencas hidrográficas de la zona semiárida de Chile. 161 p. Informe final Proyecto Cuencas CONAF-JICA. Marzo 1993-Febrero 1998. CONAF-JICA, Santiago, Chile.

Gastó, J., P. Rodrigo, e I. Aránguiz. 2002. Desarrollo de una metodología para la representación y resolución de problemas de predios rurales. p. 111-151. In Gastó J., P. Rodrigo, e I. Aránguiz (eds.) Ordenación territorial, desarrollo de predios y comunas rurales. Pontificia Universidad Católica de Chile, Facultad de Agronomía e Ingeniería Forestal, LOM Ediciones, Santiago, Chile.
Honorato, R., L. Barrales, I. Peña, y F. Barrera. 2001. Evaluación del modelo USLE en la estimación de la erosión en seis localidades entre la IV y IX región de Chile. Cien. Inv. Agr. 28:7-14.

ICONA. 1988. Agresividad de la lluvia en España. Valores del factor $\mathrm{R}$ de la ecuación universal de pérdidas de suelo. 39 p. Servicio de Publicaciones del Ministerio de Agricultura, Pesca y Alimentación, Madrid, España.

IGM. 1990. Cartas regulares de Chile. Instituto Geográfico Militar, Santiago, Chile.

Kouli, M., P. Soupios, and F. Vallianatos. 2009. Soil erosion prediction using the Revised Universal Soil Loss Equation (RUSLE) in a GIS framework, Chania, Northwestern Crete, Greece. Environ. Geol. 57:483497.

Lu, D., G. Li, G.S. Valladares, and M. Batistella. 2004. Mapping soil erosion risk in Rondonia, Brazilian Amazonia: Using RUSLE, remote sensing and GIS Land Degrad. Dev. 15:499-512.

Mitasova, H., J. Hofierka, M. Zlocha, and L.R. Iverson. 1996. Modelling topographic potential for erosion and deposition using GIS. Int. J. Geogr. Inf. Syst. 10:629641.

Oyarzún, C. 1993. Evaluación del modelo USLE para predecir pérdidas de suelo en áreas forestales de la Cuenca del Río Bío-Bío. Bosque (Valdivia) 14(1):4554.

Peña, L. 1983. Determinación de los factores R, K y C de la Ecuación Universal de Estimación de la Erosión para la Precordillera de la VII Región. Agric. Téc. (Chile) 43:151-158.

Peña, L. 1985. Erosión hídrica en trumaos de lomajes. p. 528-547. In Tosso, J. (ed.) Suelos volcánicos de Chile. Ministerio de Agricultura, Instituto de Investigaciones Agropecuarias INIA, Santiago, Chile,

Renard, K.G., G.R. Foster, G.A. Weesies, D.K. McCool, and D.C. Yoder. 1997. Predicting soil erosion by water: A guide to conservation planning with the Revised Universal Soil Loss Equation (RUSLE). Agricultural Handbook $\mathrm{N}^{\circ}$ 703. 384 p. U.S. Department of Agriculture, Washington D.C., USA.

Saco, P.M., G. R. Willgoose, and G. R.Hancock. 2007. Eco-geomorphology of banded vegetation patterns in arid and semi-arid regions. Hydrol. Earth Syst. Sci. 11:1717-1730.

Tiwari, A.K., L.M. Risse, and M.A. Nearing. 2000. Evaluation of WEPP and its comparison with USLE and RUSLE. Trans. ASAE. 43:1129-1135.

Tsuruta, K. 1999. Una experiencia invaluable, Proyecto de Cuencas CONAF-JICA. Chile Forestal 258:9. 
USDA. 1951. Soil survey manual.503 p. Soil Conservation Service, Soil Survey Staff, U.S. Dept. of Agric. Handbook. 18. U.S. Govt. Print. Off. Washington, D.C., USA.

Wischmeier, W.H., and D.D. Smith. 1978. Predicting rainfall erosion losses - A guide to conservation planning. 59 p. Agriculture Handbook N537. U.S. Department of Agriculture, Washington D.C., USA.
Zhou, P., O. Luukkanen, T. Tokola, and J. Nieminen. 2008. Effect of vegetation cover on soil erosion in a mountainous watershed. CATENA 75:319-325. 